Volume: 1

Number: 1

Page: 7 - 14

Journal of Tourism Economics and Policy

ISSN 2775-2283 (print)

https://journalkeberlanjutan.com/index.php/jtep

\title{
COMPLIANCE PREDICTORS ARE MANDATORY VEHICLE TAX
}

\section{${ }^{1}$ Ni Kadek Putri HANDAYANI, 2Ni Nengah Seri EKAYANI, 3Putu Gede Wisnu Permana KAWISANA}

Faculty of Economics and Business, University of Warmadewa, Indonesia.

Corresponding author: Putu Gede Wisnu Permana KAWISANA

Faculty of Economics and Business, University of Warmadewa, Indonesia.

Email: permanaunwar@gmail.com

\section{Article History:}

Received: 2021-03-10

Revised: 2021-04-04

Accepted: 2021-04-20

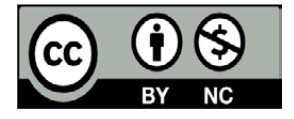

\begin{abstract}
:
The purpose of this study was to determine the predictors of motor vehicle taxpayer compliance. The population in this study were taxpayers registered at the Samsat Bersama Tabanan Office. The number of samples used in this study amounted to 100 respondents calculated based on the Slovin formula with the method of determining the sample accindental sampling and tested using multiple linear regression models with the help of SPSS 24. The data used are primary and secondary data obtained or collected by researchers directly from the data source. To obtain data in this study was carried out through questionnaires distributed to taxpayers at the Samsat Bersama Tabanan Office. The results showed that the variables of Taxpayer Awareness, Tax Sanctions, Tax Knowledge, Service Quality, Tax Socialization and the Drive Thru Samsat System had a positive effect on motor vehicle taxpayer compliance at the Samsat Joint Tabanan Office.
\end{abstract}

Keywords:

Taxpayer Compliance, Service Quality, Tax Socialization

Cite this as: HANDAYANI, N.K.P., EKAYANI, N.N.S., KAWISANA, G.W.P (2021). "Compliance Predictors Are Mandatory Vehicle Tax". Journal of Tourism Economics and Policy 1(1), 8-15. https://doi.org/10.38142/jtep.v1i1.99

\section{INTRODUCTION}

Taxes are a source of funding in carrying out state responsibilities to address social problems to improve welfare and prosperity as well as social contact between citizens and the government. Local taxes play a very important role as a source of regional income and as a support for regional development because local taxes are one of the sources of Regional Original Income (Saputra, Jayawarsa, et al., 2019; Saputra, Sara, et al., 2019; Sara et al., 2019). Development vehicles every year to experience enhancement. This condition can certainly be exploited by samsat office for tax purposes to the owner of the motor vehicle. The rapid development of the times has made all levels of society increasingly motivated to be able to meet all their needs (Harrison \& Donnelly, 2011; Priliandani \& Saputra, 2019; Sawani et al., 2016).

One of them is the need for means of transportation such as motorized vehicles (Factor, 2018; Riswan \& Kesuma, 2014). Therefore, the level of people's purchasing power for motorized vehicles to meet their needs for means of transportation is also increasing, this causes the number of motor vehicle taxpayers to increase every year, so it cannot be denied that in fact every individual must have a vehicle even more 


\section{Journal of Tourism Economics and Policy \\ ISSN 2775-2283 (print) \\ https://journalkeberlanjutan.com/index.php/jtep}

than one unit vehicle (S. Iqbal \& Sholihin, 2019; Liao et al., 2018). There are both positive and negative impacts from the increasing number of vehicles. The positive impact is an increase in motor vehicle tax revenue in an area and a negative impact, namely the number of motorized vehicles that have an impact on traffic congestion and of course in line with the level of taxpayer compliance in paying taxes (Oktaviani et al., 2018; Priliandani \& Saputra, 2019). However, in reality there are still many taxpayers who do not comply with their obligations (Perlaviciute \& Squintani, 2020; Strauss et al., 2017; Uzun \& Kilis, 2020).

Taxpayer compliance is also a mandatory phenomenon that needs attention. The optimal revenue obtained by the local government, the level of compliance of taxpayers is very fair in making it all happen (Oktaviani et al., 2018; Viaene \& Zilcha, 2013). The phenomenon that occurs in society is that there are still many taxpayers who are negligent in fulfilling tax obligations, especially in paying motor vehicle taxes. This is evidenced by the many differences in the number of motorized vehicles that pay taxes compared to the number of registered motor vehicles. Seeing this phenomenon, the demand for vehicles is getting higher and the number of motor vehicle taxpayers has also increased (Factor, 2018). The increase in motor vehicles can certainly have a positive impact on local governments (Atmadja \& Saputra, 2018), because of increasing ownership and or control of a motor vehicle, it is expected taxes to be received by the local government of the type of vehicle tax also increased to increase (Furqoni \& Rosyadi, 2019; Gendron et al., 2001; Kartika, 2017; Perkins, 2009). The problem that arises at this time is that the government is still not optimal in increasing tax revenue from motorized vehicle taxes because there are still many taxpayers who are not obedient in carrying out their tax obligations (Factor, 2018; Jordan, 2014; Norton, 2018). To maximize motor vehicle tax collection, of course, we must pay attention to several factors that affect motor vehicle taxes, including Taxpayer Awareness, Tax Sanctions, Tax Knowledge, Service Quality, Tax Socialization, and the Samsat Drive-Thru System. Based on the background described above, research was carried out on " Predictors of Motor Vehicle Taxpayer Compliance ".

Taxpayer awareness is a person's good faith to fulfill the obligation to pay taxes based on a sincere conscience. The higher level of awareness of the taxpayer, then the understanding and implementation of tax obligations, the better so to increase compliance (Harrison \& Donnelly, 2011; Kirchmaier et al., 2018; Priliandani \& Saputra, 2019; Yasa \& Prayudi, 2019). Form of consciousness in paying taxes that encourage taxpayers to pay taxes, which can be measured by the following indicators: The push yourself, the public trust, rights and obligations, Knowing, understanding the motor vehicle tax (Factor, 2018; Liao et al., 2018; Riswan \& Kesuma, 2014). Tax sanctions are a guarantee that the provisions of tax laws and regulations (taxation norms) will be obeyed / obeyed / obeyed. Or in other words, tax sanctions are a deterrent (preventive) so that taxpayers do not violate taxation norms (Amrullah, 2008; Priliandani \& Saputra, 2019) . The implementation of tax sanctions can be measured by the following indicators: Suitability of Tax Sanctions, Tax Sanctions on Taxpayer discipline, Imposing sanctions on taxpayers, Tax sanctions based on the size of the violation (Chiou \& Shu, 2019; Dwijayanti \& Hamidah, 2017).

Knowledge of taxation is a taxpayer's understanding of proper and correct taxation procedures used to carry out his taxation obligations in accordance with applicable regulations (Bromley \& Orchard, 2015; Thanitcul \& Srinopnikom, 2019). The indicators used to measure tax knowledge are: Taxpayer's insight into taxation. With the following statement: Rights and obligations in taxation, procedures for paying motor vehicle taxes, obtaining information, administrative sanctions , punctuality in paying motor vehicle taxes (Sari et al., 2015). Taxpayers will feel 


\section{Journal of Tourism Economics and Policy \\ ISSN 2775-2283 (print) \\ https://journalkeberlanjutan.com/index.php/jtep}

satisfied with the services provided if the tax officers carry out their duties in a professional, disciplined and transparent manner. Indicators used to measure the quality of public services are: Physical Evidence (tangibles), assurance, Reliability, Responsiveness, empathy. The indicators used to measure the socialization of taxation are: Tax counseling, discussions with taxpayers or community leaders, direct information from banners, the Website of the Directorate General of Taxes, and so on (Priliandani \& Saputra, 2019).

With the Samsat Drive Thru hopefully more people yan g enthusiastic in fulfilling their tax obligations because without waiting for a long time and Service given easily, abbr at, secure and comfortable (Berzins et al., 2019; Jensen, 2005; Priliandani \& Saputra, 2019). The indicators used to measure the drive thru samsat system are: The procedure for paying taxes using the drive thru samsat system, the use of the drive thru samsat system in paying motor vehicle taxes, paying taxes using the samsat drive thru can save time, the attitude of officers in serving system users samsat drive thru, where the drive thru region is (J. Iqbal \& Sidhu, 2019; Stevanović, 2016). Motor vehicle taxpayer compliance can be defined as the obedience or discipline of taxpayers in complying with or carrying out all laws governing requirements, mechanisms and procedures regarding taxes (Efferin, 2015; Oates, 1972). Tax compliance can be measured by the following indicators: Obligation to pay taxes, taxpayers to report and make payments on time, Complete data in paying Motor Vehicle Taxes (Dwijayanti \& Hamidah, 2017; S. Iqbal \& Sholihin, 2019).

\section{METHODS}

This research was conducted at the Joint Samsat Office, Tabanan-Bali Regency, which is located at Jl. Katamso No.6, Dajan Peken, Tabanan. The population in this study were all taxpayers registered at the Samsat Bersama Office of Tabanan Regency until 2019, namely 425,899 taxpayers. Sample used were 100 people. Oversight of the method taking samples using accidental sampling. Data analysis technique with multiple linear regression. However, prior to data analysis, data was collected using survey techniques. Test the validity and reliability of the research instrument was still carried out and continued with the classical assumption test.

\section{RESULT AND DISCUSSION}

The classical assumption test is carried out to test whether there are deviations from the classical assumptions in the regression equation obtained. The results of the classical assumption test are as follows: Normality test, Obtained Asymp.Sig. ( 2 tailed) value of $0,062>0.05$, it can be said that the data is normally distributed. Multicollinearity, It is obtained that the tolerance value of each variable is greater than 0.1 and the VIF value of each variable is less than 10, so it can be concluded that there is no multicollinearity relationship in the regression model. Heteroscedasticity, It can be seen that the significance value of each variable is greater than a (0.05), so it can be concluded that there is no heteroscedasticity in the regression model. Regression analysis is a multivariate statistical technique used to test the effect of a variable number of independent the dependent variable. From the results of multiple linear regression analysis, multiple linear regression equations can be prepared as follows:

$\mathrm{Y}=3,520+0,111 \mathrm{X}_{1}+0,122 \mathrm{X}_{2}+0,201 \mathrm{X}_{3}+0,193 \mathrm{X}_{4}+0,091 \mathrm{X}_{5}+0,130 \mathrm{X}_{6}$

Based on this equation, the effect of taxpayer awareness, tax sanctions, knowledge of taxation, service quality, tax socialization, the Samsat Drive-Thru system is assumed to be fixed, so taxpayer compliance can be described as follows: Coefficient of regression awareness of the taxpayer $\left(\mathrm{X}_{1}\right)$ positive value of 0,111 means that if the consciousness of taxpayers increased by 1 unit, assuming the sanction tax, 


\section{Journal of Tourism Economics and Policy \\ ISSN 2775-2283 (print) \\ https://journalkeberlanjutan.com/index.php/jtep}

tax knowledge, quality of care, socialization taxation, System Samsat Drive-Thru remains the taxpayer compliance agencies The Office of the Joint Samsat Tabanan district will have increased by 0,111 . Coefficient of regression sanction taxes $\left(\mathrm{X}_{2}\right)$ positive value of 0,122 means that if sanctions taxes increased by 1 unit assuming awareness of taxpayers, tax knowledge, quality of care, socialization taxation, System Samsat Drive-Thru remains the taxpayer compliance in the Office Samsat with Tabanan Regency will experience an increase of 0, 122 (Priliandani \& Saputra, 2019; Sawani et al., 2016; Yasa \& Prayudi, 2019).

The regression coefficient value of the tax knowledge variable (X3) is positive at 0,201 meaning that if tax knowledge increases by 1 unit with the assumption of taxpayer awareness, tax sanctions, service quality, tax socialization, the Samsat Drive-Thru system is fixed, taxpayer compliance in the Office Samsat with Tabanan Regency will increase by 0, 201. Regression coefficient value variable quality of service $\left(\mathrm{X}_{4}\right)$ positive value of 0,193 means that if the quality of services increased by 1 unit assuming consciousness taxpayer, sanctions taxes, tax knowledge, socialization taxation, System Samsat Drive-Thru remains the taxpayer compliance in the Office Samsat with Tabanan Regency will experience an increase of 0,193 (Berzins et al., 2019; Chiou \& Shu, 2019; Islam et al., 2020). The regression coefficient value of the tax socialization variable $\left(\mathrm{X}_{5}\right)$ is positive at 0 , 09, meaning that if the socialization of taxation increases by 1 unit, assuming taxpayer awareness, tax sanctions, tax knowledge, service quality, the Samsat Drive-Thru system is fixed, taxpayer compliance in the office Samsat with Tabanan Regency will increase by 0, 091 (Compa et al., 2019; Oates, 1972; Tang et al., 2017).

Coefficient of regression Systems Samsat Drive-Thru (X6) positive value of 0, 130 means that if the system is Samsat Drive-Thru enhanced with the assumption that consciousness taxpayer, penalty taxes, tax knowledge, quality of service, and the socialization of taxation remain the taxpayer compliance in the Office Together Samsat Tabanan district will have increased by 0, 130 (S. Iqbal \& Sholihin, 2019; Oktaviani et al., 2018; Tang et al., 2017). The feasibility test of the model (F test) aims to determine the feasible multiple linear regression model used as an analytical tool that tests the effects of independent variables on the dependent variable. If the ANOVA significance value is less than 0.05, the model is feasible. Based on the results of the $\mathrm{F}$ test, it was obtained a significance value of 0.000 . test of significance by comparing the value of the probability of significance to the value of the significance level predefined in the amount of $0.000<0.05$. This means that the regression model is feasible to use (model fit) (Gaughan \& Javalgi, 2018; Priliandani \& Saputra, 2019; Stevanović, 2016).

The t-test is a test of the coefficient of each independent variable to determine how much influence the independent variable has on the dependent variable. If $\operatorname{sig} t$ is greater than 0.05 then Ho is accepted. Likewise, if sig $t$ is less than 0.05, then Ho is rejected, which means that there is a significant relationship between the independent variable and the dependent variable. Based on table 21 above, it can be seen that the significant results of the $t$ statistical test for each variable, namely: Testing of taxpayer awareness of taxpayer compliance (S. Iqbal \& Sholihin, 2019; Priliandani \& Saputra, 2019; Tang et al., 2017). Based on the hypothesis testing results obtained by the magnitude of the beta coefficient of 0,111 with positive direction and the significant $t$-value for $0,008<$ of the significant value of $a(0.05)$, this air- meaning awareness of taxpayers influence positively and significantly on tax compliance so that $\mathrm{H} 1$ in this study accepted (Islam et al., 2020; Priliandani \& Saputra, 2019). Testing tax sanctions on taxpayer compliance. Based on the hypothesis testing results obtained by the magnitude of the beta coefficient of 0,122 with positive direction and the significant value of $t$ for $0,011<$ of the significant value of a (0.05), this means that the sanction tax impact positively and significantly on tax 


\section{Journal of Tourism Economics and Policy \\ ISSN 2775-2283 (print) \\ https://journalkeberlanjutan.com/index.php/jtep}

compliance so that $\mathrm{H} 2$ in this research is accepted. Testing knowledge of taxation on taxpayer compliance. Based on the results of the test of hypotheses obtained the magnitude of the beta coefficient of 0,201 with positive direction and the significant value of $t$ for 0,001 < of the significant value of a (0.05), this means tax knowledge influence positively and significantly on mandatory compliance $\mathrm{p}$ invited so that $\mathrm{H} 3$ in this study accepted (Priliandani \& Saputra, 2019; Stevanović, 2016; Tang et al., 2017).

Testing the quality of service on taxpayer compliance. Based on the hypothesis testing results obtained by the magnitude of the beta coefficient of 0,193 with positive direction and the significant value of $t$ for $0,001<$ of the significant value of a (0.05), this means that the quality of service affects positively and significantly on tax compliance so that $\mathrm{H} 4$ in this research is accepted. Testing of tax socialization on taxpayer compliance. Based on hypothesis one testing obtained the magnitude of the beta coefficient of 0,091 with positive direction and the significant value of $t$ for 0 , 036 < of the significant value of a (0.05), this means the socialization of taxation affects positively and significantly to compliance taxes so that $\mathrm{H} 5$ in this study accepted (Chiou \& Shu, 2019; Gaughan \& Javalgi, 2018; Priliandani \& Saputra, 2019). Testing the Samsat Drive-Thru System for taxpayer compliance. Based on the hypothesis testing results obtained by the magnitude of the beta coefficient of 0,130 with positive direction and the significant value of $t$ for $0,017<$ of the significant value of a (0.05), and mean System Samsat Drive-Thru influence positively and significantly on tax compliance so that H 6 in this study accepted (Chiou \& Shu, 2019; Islam et al., 2020; Priliandani \& Saputra, 2019; Saputra, Trisnadewi, et al., 2019; Saputra \& Kawisana, 2021; Stevanović, 2016).

\section{CONCLUSION}

Awareness of taxpayer effects positively da $\mathrm{n}$ significantly influence taxpayer compliance, which means increasing the awareness of taxpayers tax compliance will also increase. Tax sanctions have a positive and significant effect on taxpayer compliance, which means that with the increasing tax sanctions, the taxpayer compliance will also increase. Tax knowledge has a positive and significant effect on taxpayer compliance, which means that with the increasing knowledge of taxation, taxpayer compliance will also increase. Service quality has a positive and significant effect on taxpayer compliance, which means that the higher the quality of service, the taxpayer compliance will also increase. Tax socialization has a positive and significant effect on taxpayer compliance, which means that the increasing socialization of taxation will increase taxpayer compliance. The Samsat Drive-Thru system has a positive and significant effect on taxpayer compliance, which means that the increasingly samsat drive-thru system will increase taxpayer compliance.

For the Samsat Office with Tabanan Regency, So that taxpayers realize that taxes are a source of state income so that taxpayers will consciously pay their taxes. For tax officers, it is necessary to socialize the sanctions if the taxpayer is late paying motor vehicle tax and also to socialize the rights and obligations of people who have motorized vehicles to pay taxes every year for the welfare of the country. For Further Research, This research is only limited to the Samsat Tabanan Office, so it is hoped that further researchers will develop research sites to research other institutions. Further researchers are also expected to develop research variables that have not been studied in research, such as: tax audits, trust in tax officers, and good perceptions of government. 


\section{Journal of Tourism Economics and Policy \\ ISSN 2775-2283 (print) \\ https://journalkeberlanjutan.com/index.php/jtep}

\section{REFERENCES}

Amrullah, M. M. (2008). Implementasi Theory of Planned Behavior dalam Mendeteksi Minat dan Perilaku Fraud pada Sektor Publik | 1. Universitas Brawijaya, 2016, $1-20$.

Atmadja, A. T., \& Saputra, K. A. K. (2018). Determinant Factors Influencing The Accountability of Village Financial Management. Academy of Strategic Management Journal, 17(1), 1-9.

Berzins, J., Bøhren, Ø., \& Stacescu, B. (2019). Dividends and taxes: The moderating role of agency conflicts. Journal of Corporate Finance, 58(January 2018), 583-604. https://doi.org/10.1016/j.jcorpfin.2019.07.003

Bromley, P., \& Orchard, C. D. (2015). Managed Morality: The Rise of Professional Codes of Conduct in the U . S . Nonprofit Sector. Nonprofit and Voluntary Sector Quarterly, 3O(November), 1-24. https://doi.org/10.1177/0899764015584062

Chiou, C. L., \& Shu, P. G. (2019). How does foreign pressure affect a firm's corporate social performance? Evidence from listed firms in Taiwan. Journal of Multinational Financial Management, https://doi.org/10.1016/j.mulfin.2019.04.006

$$
\text { 51(510), }
$$

$1-22$.

Compa, M., Alomar, C., Wilcox, C., van Sebille, E., Lebreton, L., Hardesty, B. D., \& Deudero, S. (2019). Risk assessment of plastic pollution on marine diversity in the Mediterranean Sea. Science of the Total Environment, 678, 188-196. https://doi.org/10.1016/j.scitotenv.2019.04.355

Dwijayanti, Y. W., \& Hamidah. (2017). Niat dan perilaku Wajib Pajak Orang Pribadi Mengikuti Program Tax Manesty. Jurnal AKuntansi Universitas Jember, 15(1), 1225.

Efferin, S. (2015). Akuntansi, Spritualitas dan Kearifan Lokal Beberapa Agenda Penelitian Kritis. Jurnal Akuntansi Multiparadigma, 6(3), 466-480. https://doi.org/10.18202/jamal.2015.12.6037

Factor, R. (2018). Reducing traffic violations in minority localities: Designing a traffic enforcement program through a public participation process. Accident Analysis and Prevention, 121(July), 71-81. https://doi.org/10.1016/j.aap.2018.09.005

Furqoni, I., \& Rosyadi, S. (2019). Collaborative Governance in Corporate Social Responsibility Forum in Banyumas Regency. Jurnal Bina Praja, 21, 209-217. https://doi.org/10.21787/jbp.11.2019.209-217

Gaughan, P. H., \& Javalgi, R. (Raj) G. (2018). A framework for analyzing international business and legal ethical standards. Business Horizons, 61(6), 813-822. https://doi.org/10.1016/j.bushor.2018.07.003

Gendron, Y., Cooper, D. J., \& Townley, B. (2001). In the name of accountability -State auditing, independence and new public management. Accounting, Auditing \& Accountability Journal, 14(3), 278-310. https://doi.org/10.1108/EUM0000000005518

Harrison, C., \& Donnelly, I. A. (2011). A theory of smart cities. 55th Annual Meeting of the International Society for the Systems Sciences 2011.

Iqbal, J., \& Sidhu, M. S. (2019). A taxonomic overview and pilot study for evaluation of Augmented Reality based posture matching technique using Technology Acceptance Model. Procedia Computer Science, 163, 345-351. https://doi.org/10.1016/j.procs.2019.12.117

Iqbal, S., \& Sholihin, M. (2019). The role of cognitive moral development in tax compliance decision making. International Journal of Ethics and Systems, 35(2), 227-241. https://doi.org/10.1108/ijoes-10-2018-0152 


\section{Journal of Tourism Economics and Policy \\ ISSN 2775-2283 (print) \\ https://journalkeberlanjutan.com/index.php/jtep}

Islam, A., Rashid, M. H. U., Hossain, S. Z., \& Hashmi, R. (2020). Public policies and tax evasion: evidence from SAARC countries. Heliyon, 6(11), e05449. https://doi.org/10.1016/j.heliyon.2020.e05449

Jensen, M. C. (2005). Takeovers: Their Causes and Consequences. SSRN Electronic Journal, 2(1), 21-48. https://doi.org/10.2139/ssrn.173455

Jordan, I. (2014). Corporate Governance in the Public Sector. Observatoire de La Société Britannique, 16, 37-50. https://doi.org/10.4000/osb.1706

Kartika, R. S. (2017). Local Government Readiness in Developing SIDa Roadmap in Banten, West Sumatera, and Bali. Jurnal Bina Praja, 9(1), 127-136. https://doi.org/10.21787/jbp.09.2017.127-136

Kirchmaier, I., Prüfer, J., \& Trautmann, S. T. (2018). Religion, moral attitudes and economic behavior. Journal of Economic Behavior and Organization, 148, 282300. https://doi.org/10.1016/j.jebo.2018.02.022

Liao, S., Hong, J.-C., Wen, M.-H., Pan, Y.-C., \& Wu, Y.-. (2018). Applying Technology Acceptance Model (TAM) to explore Users' Behavioral Intention to Adopt a Performance Assessment System for E-book Production. EURASIA Journal of Mathematics, Science and Technology Education, 14(10). https://doi.org/10.29333/ejmste/93575

Norton, S. D. (2018). Suspicion of money laundering reporting obligations: Auditor compliance, or sceptical failure to engage? Critical Perspectives on Accounting, 50, 56-66. https://doi.org/10.1016/j.cpa.2017.09.003

Oates, W. E. (1972). Fiscal Decentralization and Economic Development. National Tax Journal, 46.

Oktaviani, R. M., Srimindarti, C., \& Hardiningsih, P. (2018). Peran religionsity sebagai pemoderasi hubungan money ethics terhadap upaya tax evasion. Jurnal Akuntansi, 22(1), 105-118. https://doi.org/10.24912/ja.v22i1.325

Perkins, H. A. (2009). Out from the (Green) shadow? Neoliberal hegemony through the market logic of shared urban environmental governance. Political Geography, 28(7), 395-405. https://doi.org/10.1016/j.polgeo.2009.09.007

Perlaviciute, G., \& Squintani, L. (2020). Public Participation in Climate Policy Making: Toward Reconciling Public Preferences and Legal Frameworks. One Earth, 2(4), 341-348. https://doi.org/10.1016/j.oneear.2020.03.009

Priliandani, N. M. I., \& Saputra, K. A. K. (2019). Pengaruh Norma Subjektif Dan Sosialisasi Perpajakan Terhadap Kepatuhan Wajib Pajak Hotel Dan Restoran. Krisna: Kumpulan Riset Akuntansi, 11(1), 13-25.

Riswan, R., \& Kesuma, Y. F. (2014). Analisis Laporan Keuangan sebagai dasar dalam Penilaian Kinerja Keuangan PT. Budi Satria Wahana Motor. Jurnal Akuntansi Dan Keuangan, 5(1). https://doi.org/10.36448/jak.v5i1.449

Saputra, K. A. K., Jayawarsa, A. A. K., \& Anggiriawan, P. B. (2019). Asset Dan Profesional I Sme Untuk Meningkatkan Pendapatan Asli Daerah ( PAD ). Jurnal Riset Akuntansi Dan Bisnis Airlangga, 4(1), 607-622.

Saputra, K. A. K., \& Kawisana, P. G. W. P. (2021). Analysis Of The Influence Of Power , Auditor Experience And Task Complexity On Audit Judgment. Palarch's Journal Of Archaeology Of Egypt/Egyptology, 18(4), 6370-6379.

Saputra, K. A. K., Sara, I. M., Jayawarsa, A. A. K., \& Pratama, I. G. S. (2019). Management of Village Original Income in The Perspective of Rural Economic Development. International Journal of Advances in Social and Economics, 1(2), 52. https://doi.org/10.33122/ijase.v1i2.40

Saputra, K. A. K., Trisnadewi, A. A. A. E., Anggiriawan, P. B., \& Kawisana, P. G. W. P. (2019). Kebangkrutan Lembaga Perkreditan Desa (Lpd) Berdasarkan Analisis 


\section{Journal of Tourism Economics and Policy \\ ISSN 2775-2283 (print) \\ https://journalkeberlanjutan.com/index.php/jtep}

Berbagai Faktor. Jurnal Ilmiah Akuntansi, 4(1), 1-23. https://doi.org/10.23887/jia.v4i1.17250

Sara, I. M., Saputra, K. A. K., \& Jayawarsa, A. A. K. (2019). Profesionalisme Pengelolaan Pendapatan Asli Desa Untuk Meningkatkan Pembangunan Ekonomi Pedesaan. ISEI Economic Review, III(2), 45-53.

Sari, D. P., Triyuwono, I., Rosidi, \& Kamayanti, A. (2015). Human's Behavior towards Income in the Perspective of Mother Teresa. Procedia - Social and Behavioral Sciences, 211 (September), https://doi.org/10.1016/j.sbspro.2015.11.130

977-983.

Sawani, Y., Abdillah, A., Rahmat, M., Noyem, J. A., \& Sirat, Z. (2016). Employer's Satisfaction on Accounting Service Performance: A Case of Public University Internship Program. Procedia - Social and Behavioral Sciences, 224(August 2015), 347-352. https://doi.org/10.1016/j.sbspro.2016.05.386

Stevanović, M. (2016). The Role of Financial Perspective of Entrepreneurship and Rural Development for the Purpose of Strengthening Serbian Economy. Procedia Social and Behavioral Sciences, 221, 254-261. https://doi.org/10.1016/j.sbspro.2016.05.113

Strauss, K., Parker, S. K., \& O'Shea, D. (2017). When does proactivity have a cost? Motivation at work moderates the effects of proactive work behavior on employee job strain. Journal of Vocational Behavior, 100, 15-26. https://doi.org/10.1016/j.jvb.2017.02.001

Tang, T., Mo, P. L. L., \& Chan, K. H. (2017). Tax collector or tax avoider? An investigation of intergovernmental agency conflicts. Accounting Review, 92(2), 247-270. https://doi.org/10.2308/accr-51526

Thanitcul, S., \& Srinopnikom, T. (2019). Monetary penalties: An empirical study on the enforcement of thai insider trading sanctions. Kasetsart Journal of Social Sciences, 40(3), 635-641. https://doi.org/10.1016/j.kjss.2018.01.013

Uzun, A. M., \& Kilis, S. (2020). Investigating antecedents of plagiarism using extended theory of planned behavior. Computers and Education, 144(January), 103700. https://doi.org/10.1016/j.compedu.2019.103700

Viaene, J. M., \& Zilcha, I. (2013). Public funding of higher education. Journal of Public Economics, 108, 78-89. https://doi.org/10.1016/j.jpubeco.2013.09.008

Yasa, I. N. P., \& Prayudi, M. A. (2019). Nilai-nilai etika berbasis kearifan lokal dan perilaku kepatuhan perpajakan. Jurnal Ekonomi Dan Bisnis, 22(2), 361-390. https://doi.org/10.24914/jeb.v22i2.2527 